\title{
Particulate matter and organic carbon budgets for the Gulf of Lions (NW Mediterranean)
}

\author{
Xavier DURRIEU DE MADRON ${ }^{\text {a* }}$, Abderrazzak ABASSI a, Serge HEUSSNER ${ }^{\text {a }}$, André MONACO a, \\ Jean Claude ALOISI a, Olivier RADAKOVITCH ${ }^{\text {b }}$, Pierre GIRESSE ${ }^{\text {a }}$, Roselyne BUSCAIL a , \\ Philippe KERHERVE a
}

${ }^{a}$ CEFREM, CNRS, UMR 5110, université de Perpignan, 52, avenue de Villeneuve, 66860 Perpignan cedex, France

${ }^{\mathrm{b}}$ CEREGE, BP 80, 13545 Aix-en-Provence, France

Received 27 May 1999; revised 3 December 1999; accepted 8 December 1999

\begin{abstract}
An analysis of sedimentological, sediment trap and hydrological data was performed to investigate the transport and fate of particulate matter in the Gulf of Lions. The sedimentological properties outline the major sedimentary units of the shelf (Rhone prodelta, mid-shelf mud belt, outer shelf) and slope. The geometry of these sedimentary units and the southwestwards increase of particulate fluxes on the slope highlight the influence of the general cyclonic circulation on the dispersion of land-derived particulate matter. Considering the known input and output terms, budgets of particulate matter and organic carbon in the Gulf of Lions are proposed. Inputs were river supply, atmospheric deposition and primary production; outputs were sediment burial and advective export on the slope. Degradation of particulate organic carbon in the water column and at the sediment-water interface was also estimated. Mass and POC budgets were balanced within uncertainties. Nevertheless, these results illustrate the difficulty in establishing budgets based on elements estimated at different time scales, for which the system is not necessarily in a steady state. C 2000 Ifremer/CNRS/IRD/Éditions scientifiques et médicales Elsevier SAS
\end{abstract}

\section{Mediterranean Sea / Gulf of Lions / sediment / flux / organic carbon and mass budgets}

Résumé - Bilans de matière et de carbone organique particulaires dans le golfe du Lion (Méditerranée nord-occidentale). Le dépôt et l'exportation de matière particulaire dans le golfe du Lion sont présentés au travers de résultats sédimentologiques, hydrologiques et de flux particulaires. Les principales unités sédimentaires sont mises en évidence sur le plateau (prodelta rhodanien, vasière médiane et plateau externe) et sur la pente. La déflexion des unités sédimentaires vers le sud-ouest et l'augmentation des flux particulaires actuels sur la pente occidentale soulignent le rôle essentiel de la circulation moyenne cyclonique sur la dispersion de matériel continental. En considérant les termes d'entrée et de sortie connus, des bilans massiques de matière particulaire et de carbone organique particulaire ont été établis. Les termes d'entrée sont les apports fluviatiles, les dépôts atmosphériques et la production phytoplanctonique. Les pertes du système sont le piégeage dans les sédiments et l'exportation vers le large (flux advectifs le long de la pente). La dégradation du carbone organique particulaire dans la colonne d'eau et à l'interface eau-sédiment est également estimée. Les bilans de masse et de COP apparaissent équilibrés compte tenu des incertitudes. Ces résultats illustrent néanmoins la difficulté à établir des bilans basés sur des éléments estimés à différentes échelles de temps, pour lesquelles le système n'est pas nécessairement stationnaire. (C) 2000 Ifremer/CNRS/IRD/Éditions scientifiques et médicales Elsevier SAS

Méditerranée / golfe du Lion / sédiment / flux / bilans de masse et de carbone organique

\footnotetext{
* Correspondence and reprints:

E-mail address: demadron@univ-perp.fr (X. DURRIEU DE MADRON).
} 


\section{INTRODUCTION}

Continental margins are critical buffer regions between land and open ocean. The high biological productivity of the coastal waters, linked to nutrient inputs from land and coastal upwellings, and the terrigenous inputs of particulate organic matter make this zone an area of high organic matter deposition. Besides this deposition, physical processes occurring at the shelf edge export matter to the deeper environment. Estimates on the importance of such transfers between the shelf regions and the deep sea are needed to develop budgets at the world scale. This is one of the major aims of the JGOFS (Joint Global Ocean Flux Studies) and LOICZ (Land Ocean Interactions in the Coastal Zone) programs [5, 23].

The objective of this paper is to estimate the recent deposition and export of particulate matter (PM) and, more specifically, particulate organic carbon (POC) in the Gulf of Lions. It further aims at drawing PM and POC budgets by considering the shelf and slope as a single box system. These budgets use river supply, atmospheric deposition and primary production as inputs, and the sediment deposition, as well as degradation and advective transport of matter on the slope as outputs. Here, we describe and estimate the output components, while the input components are taken from the literature. Information needed for the first part of the work was gained through two approaches: 1) retrospective analysis of existing sedimentological and particle flux data, and 2) field investigations to improve the knowledge on secular burial of material on the shelf and to estimate the export of PM to the deep basin.

The current configuration of the Gulf of Lions continental shelf is the heritage of the evolution of this area since the Holocene transgression, which occurred approximately 20000 years BP. Got and Aloïsi [22] synthesized initial studies (1971-1986) on the structure, thickness, extension and nature of Holocene deposits in the Gulf of Lions. They estimated from the sediment volume accumulated during the last sea-level rise that $70 \%$ of particle inputs were trapped on the shelf and $30 \%$ were transported to the slope and basin. More recently, Zuo et al. [43, 44] refined this first estimate by calculating sedimentation rates over the last 100 years (secular time scale) inferred from ${ }^{210} \mathrm{~Pb}$ profiles. They estimated that the total secular accumulation rate of sediment in the Gulf of Lions $\left(10 \times 10^{6} \mathrm{~T} \cdot \mathrm{y}^{-1}\right)$ was $4-5$ times lower than the Holocene deposit $\left(44 \times 10^{6} \mathrm{~T} \cdot \mathrm{y}^{-1}\right)$, and attributed this discrepancy to temporal variability of sediment inputs and deposition. Two cruises (ECOCOT 1 and 2) were made in 1994 and 1996 to complement the geophysical and sedimentological data sets gathered during earlier studies. The old and new data sets were pooled to define the geometry and the nature of the surficial sediments, as well as the mean secular burial rate for the major sedimentary units.

We further used existing moored sediment trap data to evaluate the downward fluxes and chemical composition of the PM on the upper continental slope, i.e. between 200 and $1000 \mathrm{~m}$ depth (figure 1). These moorings were deployed in the Lacaze-Duthiers Canyon in 1984-1985 [32], in the Grand-Rhone Canyon in 1988-1989 [34], and in the Planier, Sète, and Lacaze-Duthiers Canyons from October 1993 to October 1995 [25]. Sediment trap fluxes on the slope were compared with surficial sediment accumulation rates to estimate the degradation rate of POC at the sediment-water interface.

The advective export of total PM and POC from the shelf to the adjacent deep basin was estimated from two different hydrographic surveys performed in February 1995 and July 1996 [27].

The first section of this paper summarizes the analytical methods. The second and third sections describe the sediment burial and the advective exports of PM and POC. The fourth section describes the inputs of POC to the system. The fifth section focuses on the POC degradation and the last section discusses the balance of the PM and POC budgets.

\section{METHODS}

\subsection{Sedimentological and geochemical properties of the sediment}

High-resolution seismic reflection surveys were performed to identify the geometry of the shelf Quaternary deposits and to trace the limits of the sedimentary domains, particularly the Holocene unit. This latter unit was subsequently sampled by coring to characterize the main sediment properties. 
Granulometric analyses were made using a Sedigraph 5100 (Micrometric Inc.) after wet sieving through a $50 \mu \mathrm{m}$ mesh.

Total carbon was analyzed by combustion in a LECO CS 125 carbon analyzer. POC was measured in the same way after removing inorganic carbon by progressive and controlled acidification with $\mathrm{HCl}$ or $\mathrm{H}_{3} \mathrm{PO}_{4}[12]$.

Concentration of ${ }^{210} \mathrm{~Pb}\left(\mathrm{~T}_{1 / 2}=22.3 \mathrm{y}\right)$ was determined indirectly by measuring its granddaughter ${ }^{210} \mathrm{Po}$. ${ }^{210} \mathrm{Po}$ was extracted from sediment samples by complete acid digestion, spontaneously deposited on a silver disk and measured by total alpha counting. Excess ${ }^{210} \mathrm{~Pb}\left({ }^{210} \mathrm{~Pb}_{\mathrm{xs}}\right.$, the fraction of ${ }^{210} \mathrm{~Pb}$ unsupported by its radioactive parent in the sediment) was calculated by subtracting the mean of low-level ${ }^{210} \mathrm{~Pb}$ activities measured at the base of the core (assumed to be equal to the ${ }^{226} \mathrm{Ra}$ activity) from the total ${ }^{210} \mathrm{~Pb}$ activity [38].

\subsection{Sedimentation rates}

Secular sedimentation rates were generally calculated from ${ }^{210} \mathrm{~Pb}_{\mathrm{xs}}$ profiles, using the model described by DeMaster et al. [17] and Anderson et al. [4]. This model takes mixing and accumulation processes into account. Since the exponentially decreasing ${ }^{210} \mathrm{~Pb}_{\mathrm{xs}}$ distribution in the sediment can be produced by either accumulation or mixing or any combination of both processes, only maximum sedimentation and mixing rates can be calculated from the model, assuming, alternatively, each of them to be negligible. A truncation of the ${ }^{210} \mathrm{~Pb}_{\mathrm{xs}}$ profiles evidenced a surface mixed layer in the majority of the cores. In this case, apparent sedimentation rates were determined under the surface mixed layer, using a two-layer model where accumulation and mixing rates are considered constant for each layer and where mixing is assumed negligible in the deeper layer. The depth of the surface mixed layer was determined visually from

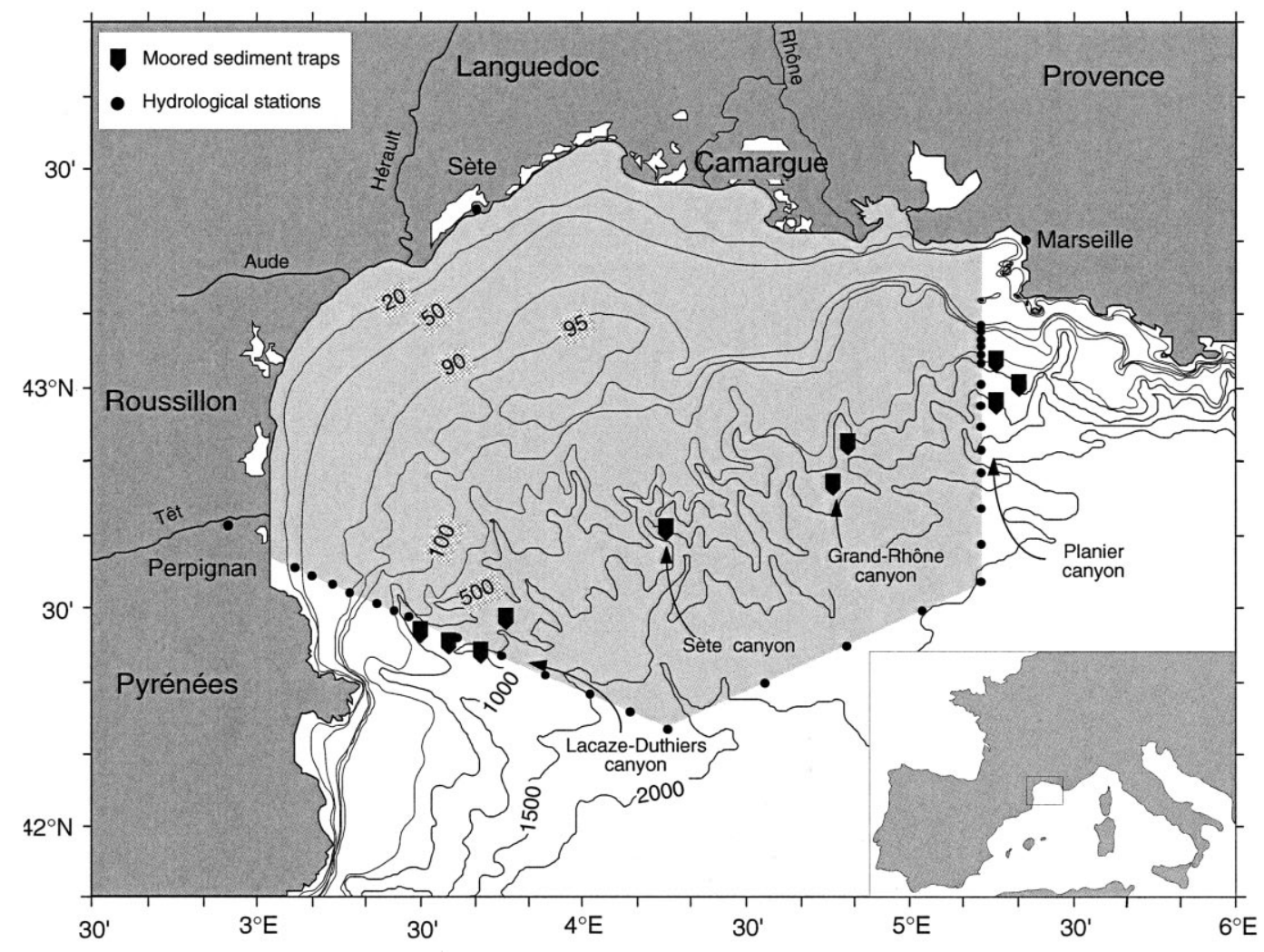

Figure 1. The continental margin of the Gulf of Lions with the location of the sediment traps mooring sites, hydrographical stations and sediment coring area (shaded area). 
the profile. This model can either calculate linear sedimentation rates $\left(\mathrm{R}\right.$ in $\mathrm{cm} \cdot \mathrm{y}^{-1}$ ) or mass accumulation rates $\left(\mathrm{r}\right.$ in $\left.\mathrm{g} \cdot \mathrm{cm}^{-2} \cdot \mathrm{y}^{-1}\right)$. In order to integrate the existing and new data sets, the linear sedimentation rates were converted to accumulation rates using the relation

$\mathrm{r}=\mathrm{R}(1-\phi) \rho$

where $\phi$ is the porosity $(\sim 0.5)$ and $\rho$ is the dry density of the sediments, assumed to be $1.6 \mathrm{~g} \cdot \mathrm{cm}^{-3}$ [44].

Sedimentation rates on the Rhone prodelta were also evaluated from the distribution of artificial radionuclides $\left({ }^{137} \mathrm{Cs}\right.$ and $\left.{ }^{134} \mathrm{Cs}\right)$. These elements are brought to the system by the effluents of nuclear power plants located along the Rhone River and from the Chernobyl accident fallout $[13,37]$.

\subsection{Particle fluxes in the water column}

Downward particle fluxes on the upper slope were measured using PPS3 sediment traps. Trap sampling rates varied between the different experiments, from 15 to 30 days. A complete description of the trap design as well as the sample processing was given by Heussner et al. [24]. The POC content of settled material was determined using the same procedure as for the sediment.

Advective export of PM along the continental slope was calculated using the geostrophic transport ([27] submitted), computed from conductivity, temperature and depth (CTD) data, as well as transmissometry data. CTD data were obtained with a SeaBird 9/11 probe, and transmissometry ( $\mathrm{Tr}$ in \%) was measured with a $25 \mathrm{~cm}$ pathlength SeaTech transmissometer. PM concentrations were converted from beam attenuation coefficient $(c=-4 \operatorname{Ln}(\operatorname{Tr}))$ measurements. POC concentrations were estimated as a fraction of the PM concentrations (about $10 \%$ in winter and $5 \%$ in summer).

\subsection{Estimation of errors}

The range of uncertainty of each term of the budget was defined as the $95 \%$ confidence interval of the mean $(\overline{\mathrm{x}})$ : $\overline{\mathrm{x}}-\mathrm{t} \frac{\mathrm{s}}{\sqrt{\mathrm{n}}} \leq \overline{\mathrm{x}} \leq \overline{\mathrm{x}}+\mathrm{t} \frac{\mathrm{s}}{\sqrt{\mathrm{n}}}$

with $\mathrm{s}$ being the standard deviation of $\mathrm{n}$ measurements from which $\bar{x}$ has been determined; $t$ is the Student parameter with $\mathrm{n}-1$ degrees of freedom at a confidence level of $95 \%$. In the absence of statistical information on the measurements, the uncertainty was arbitrarily fixed to cover most of the range of known or supposed mean values. The confidence interval of composed variables was calculated by considering the 'worst-case' combination. Its upper limit was calculated by maximizing the input terms and their derived terms, while minimizing the output terms, and vice versa for the lower limit. This does not apply to the POC degradation in the photic layer, which was considered a constant fraction of the primary production.

\section{RESULTS AND DISCUSSION}

\subsection{Definition of functional units in the sediment}

\subsubsection{Geometry of Holocene deposits}

A first representation of the sedimentation mechanisms is given by the thickness of the Holocene deposits (figure 2a). There are three major zones. The first zone is characterized by large accumulations of between 30 and $50 \mathrm{~m}$ in depth. It extends the Rhone deltaic plain to the west as far as Sète. The second zone covers most of the middle shelf west of the Rhone river mouth. The Holocene sediment thickness progressively decreases from $30 \mathrm{~m}$ to $5 \mathrm{~m}$ off shore and towards the Roussillon coast. The third zone covers the outer shelf between 90 and $200 \mathrm{~m}$ depth. It is an area with thin Holocene deposits and outcrops of relict sands.

\subsubsection{Grain size}

The sands of the inner shelf display a seaward-fining texture and merge, in water deeper than $20-30 \mathrm{~m}$, with mid-shelf muds. Jago and Barusseau [26] showed the qualitative correspondance between the grain size gradient and the seaward-attenuating wave power. The only noticeable exception is the prodeltaic accumulation zones found near the river mouths, which are composed of silty muds (figure 2b). Pelitic deposits predominantly compose the middle shelf and 

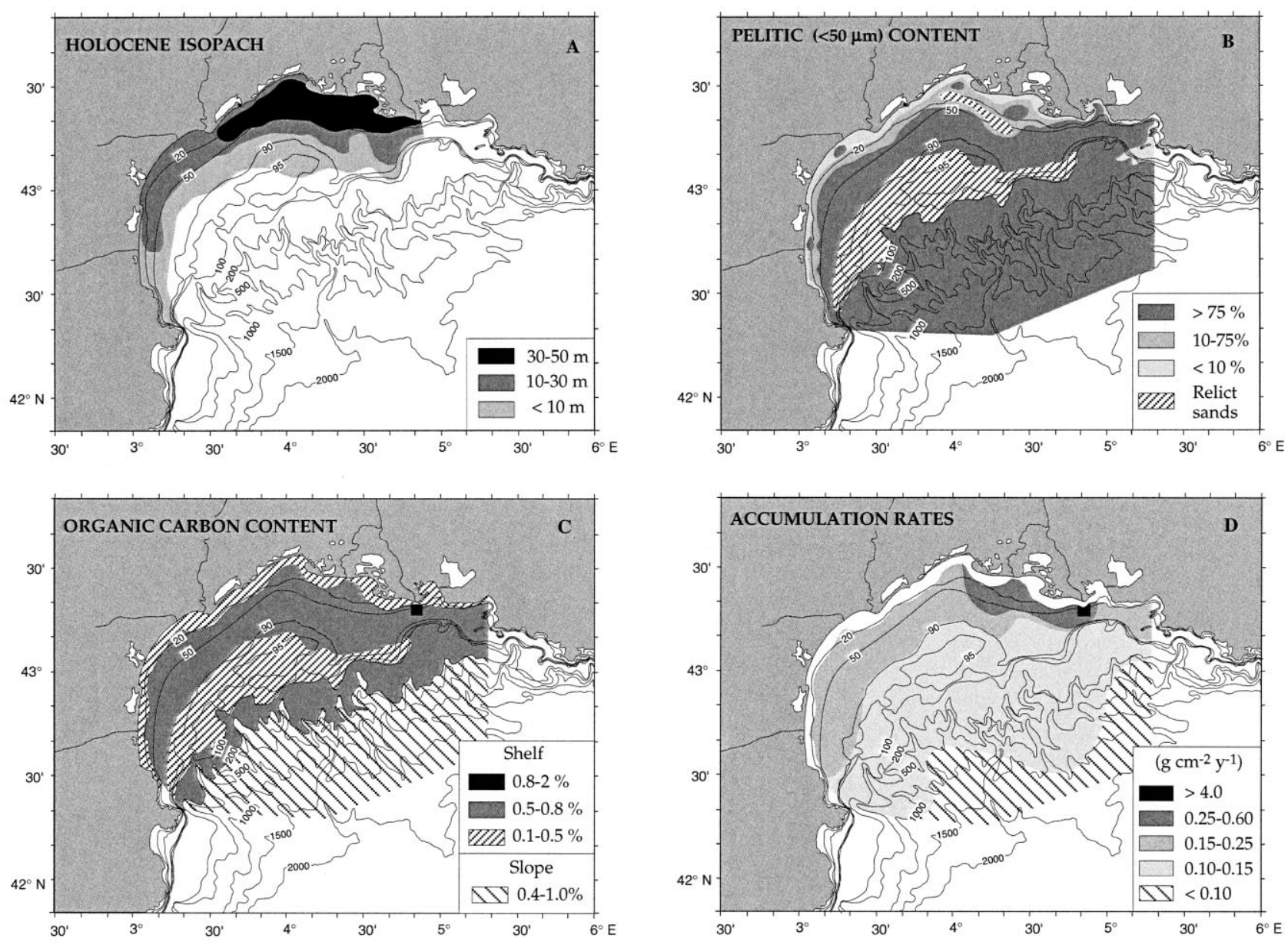

Figure 2. Spatial distribution of the Holocene sediment thickness [22] (A), pelitic content [22, 21] (B), surficial organic carbon concentration (C) and secular accumulation rates (D) in the Gulf of Lions.

the slope sediments. Muddy sands that outcrop on the outer shelf between 90 and $200 \mathrm{~m}$ represent littoral relict formations from the last eustatic low stage, that were reworked during the first phase of the eustatic sea-level rise.

\subsubsection{Organic carbon}

Organic carbon content in surficial sediments is generally low in the sandy deposits of the outer shelf $(0.25-0.5 \%)$ and especially those of the inner shelf (figure $2 c$ ). It increases $(\sim 0.6 \%)$ in the mid-shelf muddy deposits, where the pelitic fraction exceeds $75 \%$ [2]. The highest values are found in the Rhone prodeltaic deposits, which are, enriched with organic carbon $(1-2 \%)$ due to the presence of coarse ligninrich plant debris $[8,20]$. Surficial sediments of the slope down to $1700 \mathrm{~m}$ depth present intermediate organic carbon contents $(0.4-1.0 \%)$, due to the very fine texture of the sediment [9]. The highest contents on the slope are observed in muddy deposits from the various canyons $(0.6-1.0 \%)$, with northeastern canyons being richer (average $0.8 \%$ ) than southwestern canyons (average $0.7 \%$ ). Organic carbon contents on the open slope are significantly lower $(0.4-0.5 \%)$.

\subsubsection{Mass accumulation rates}

The spatial distribution of mass accumulation rates presented in figure $2 d$ summarize the 75 published values $[1,10,11,13,36,37,43,44]$. Mass accumulation rates are highest in the immediate vicinity of the Rhone river mouth where they range from 30 to 50 $\mathrm{g} \cdot \mathrm{cm}^{-2} \cdot \mathrm{y}^{-1}$ (average $40 \mathrm{~g} \cdot \mathrm{cm}^{-2} \cdot \mathrm{y}^{-1}$ ). These very 
high values were determined from three different radionuclides studies $[11,13,37]$. They are in good agreement with those estimated from seismic stratigraphy [40]. Rates decrease rapidly seaward and gradually along-shore. On the distal part of the Rhone prodelta (20 km off the coast of Camargue), they range from 0.2 to $0.6 \mathrm{~g} \cdot \mathrm{cm}^{-2} \cdot \mathrm{y}^{-1}$ (average $0.4 \mathrm{~g} \cdot \mathrm{cm}^{-2} \cdot \mathrm{y}^{-1}$ ). The rest of the shelf exhibits low rates, between 0.1 and 0.3 $\mathrm{g} \cdot \mathrm{cm}^{-2} \cdot \mathrm{y}^{-1}$. The average accumulation rate is about $0.15 \mathrm{~g} \cdot \mathrm{cm}^{-2} \cdot \mathrm{y}^{-1}$ on the mid-shelf mud belt and 0.14 $\mathrm{g} \cdot \mathrm{cm}^{-2} \cdot \mathrm{y}^{-1}$ on the outer shelf. As mentioned by Radakovitch [36] and Zuo et al. [44], sedimentation on the slope is less variable and generally decreases with increasing depth. Accumulation rates for the upper slope (200-1000 m depth) are in the range of $0.05-$ $0.12 \mathrm{~g} \cdot \mathrm{cm}^{-2} \cdot \mathrm{y}^{-1}$, with the highest values generally found in the canyons. The average rate is $0.09 \mathrm{~g}$ $\mathrm{cm}^{-2} \cdot \mathrm{y}^{-1}$. The rates on the lower slope (1 000-2 000 $\mathrm{m}$ ) range from 0.01 to $0.08 \mathrm{~g} \cdot \mathrm{cm}^{-2} \cdot \mathrm{y}^{-1}$ (average 0.03 $\left.\mathrm{g} \cdot \mathrm{cm}^{-2} \cdot \mathrm{y}^{-1}\right)$.

\subsubsection{Definition of sedimentary units}

The distribution of most sedimentological parameters indicates the predominant influence of rivers (especially the Rhone) in the coastal zone. From the dominant features summarized in the previous paragraphs, four major sedimentary units can be defined on the shelf (figure 3): (1) the Rhone proximal prodelta, (2) the distal prodelta (off Camargue), (3) the mid-shelf mud belt between 20 and $90 \mathrm{~m}$ depth, (4) the outer shelf between $90 \mathrm{~m}$ and the shelfbreak depth $(200$ $\mathrm{m})$. The continental slope is subdivided in two parts:

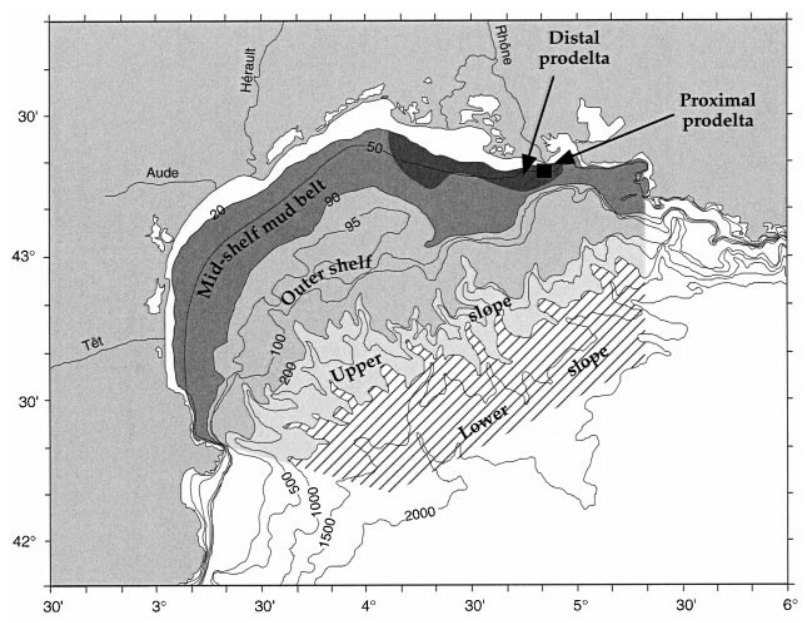

Figure 3. Limits of the sedimentary units on the continental shelf and slope of the Gulf of Lions.

(1) the upper slope between 200 and $1000 \mathrm{~m}$ depth, which is deeply incised by many canyons, and (2) the lower slope between 1000 and $2000 \mathrm{~m}$ depth.

\subsection{Output of PM and POC from the Gulf of Lions water column}

\subsubsection{Sedimentary sinks on the shelf and slope}

The annual mass accumulation $\mathrm{m}\left(\mathrm{kg} \cdot \mathrm{y}^{-1}\right)$ was estimated for the different sedimentary units by the relation $\mathrm{m}=\mathrm{S} \times \mathrm{r}$, where $\mathrm{S}$ and $\mathrm{r}$ are the surface area and the mean secular accumulation rate of each unit

Table I. Annual deposition of particulate matter and particulate organic carbon for each sedimentary unit in the Gulf of Lions.

\begin{tabular}{|c|c|c|c|c|c|c|}
\hline Sediment & Area $\left(\mathrm{km}^{2}\right)$ & $\begin{array}{l}\text { Mean accumulation rate } \\
\left(\mathrm{g} \cdot \mathrm{cm}^{-2} \cdot \mathrm{y}^{-1}\right)\end{array}$ & $\begin{array}{l}\text { Number of } \\
\text { sediment cores }\end{array}$ & $\begin{array}{l}\text { Mean POC } \\
\text { content }(\%)\end{array}$ & $\begin{array}{l}\text { Mass deposition } \\
\left(\mathrm{T} \cdot \mathrm{y}^{-1}\right)\end{array}$ & $\begin{array}{l}\text { POC deposition } \\
\left(\mathrm{T} \cdot \mathrm{y}^{-1}\right)\end{array}$ \\
\hline $\begin{array}{l}\text { Proximal Rhone } \\
\text { prodelta }\end{array}$ & 10 & $40.0 \pm 25.0$ & 3 & 2 & $4.0 \pm 2.5 \times 10^{6}$ & $8.0 \pm 5.0 \times 10^{4}$ \\
\hline $\begin{array}{l}\text { Distal Rhone } \\
\text { prodelta }\end{array}$ & 600 & $0.37 \pm 0.15$ & 7 & 1.3 & $2.2 \pm 0.9 \times 10^{6}$ & $2.9 \pm 1.2 \times 10^{4}$ \\
\hline $\begin{array}{l}\text { Mid-shelf mud } \\
\text { belt }(20-90 \mathrm{~m})\end{array}$ & 4500 & $0.15 \pm 0.04$ & 13 & 0.6 & $6.8 \pm 1.7 \times 10^{6}$ & $4.1 \pm 1.0 \times 10^{4}$ \\
\hline $\begin{array}{l}\text { Outer shelf } \\
\qquad(90-200 \mathrm{~m})\end{array}$ & 6500 & $0.14 \pm 0.10$ & 6 & 0.4 & $9.1 \pm 6.8 \times 10^{6}$ & $3.6 \pm 2.7 \times 10^{4}$ \\
\hline $\begin{array}{l}\text { Upper slope } \\
\quad(200-1000 \mathrm{~m})\end{array}$ & 3900 & $0.09 \pm 0.01$ & 27 & $\begin{array}{l}0.8^{\mathrm{a}} \\
0.7^{\mathrm{b}}\end{array}$ & $\begin{array}{l}2.2 \pm 0.3 \times 10^{6} \\
1.4 \pm 0.2 \times 10^{6}\end{array}$ & $\begin{array}{l}1.7 \pm 0.2 \times 10^{4} \\
1.0 \pm 0.1 \times 10^{4}\end{array}$ \\
\hline $\begin{array}{l}\text { Lower slope } \\
\qquad(1000-2000 \mathrm{~m})\end{array}$ & 6100 & $0.03 \pm 0.01$ & 19 & 0.7 & $1.8 \pm 0.6 \times 10^{6}$ & $1.3 \pm 0.4 \times 10^{4}$ \\
\hline
\end{tabular}

${ }^{\mathrm{a}}$ Eastern part of the upper slope $\left(\right.$ area $\left.=2400 \mathrm{~km}^{2}\right)$.

${ }^{\mathrm{b}}$ Western part of the upper slope $\left(\operatorname{area}=1500 \mathrm{~km}^{2}\right)$. 
respectively. Organic carbon accumulations were calculated in the same way by taking the mean POC concentrations for each unit (table I). The total mass accumulation on the shelf and on the slope is about $27.4 \pm 13.0 \times 10^{6} \mathrm{~T} \cdot \mathrm{y}^{-1}$. The corresponding POC accumulation is about $22.5 \pm 10.7 \times 10^{4} \mathrm{~T} \cdot \mathrm{y}^{-1}$.

\subsubsection{Advective export from the Gulf of Lions}

It is interesting to compare the orientation of the sedimentary units with the oceanic circulation (figure 4). The deposits are clearly constrained by the overall cyclonic drift that influences most of the shelf and slope and that transports the Rhone material to the southwest and, eventually, off the shelf. Monaco et al. [34] showed that the downward particle fluxes on the slope, measured with sediment traps, were 3-10 times higher at the southwestern exit of the Gulf of Lions than at its northeastern entrance.

Several hydrographic surveys have been dedicated to the description of PM advective transport between the shelf and the slope. Durrieu de Madron and Panouse [18] showed that a bottom nepheloid layer (BNL) on the shelf persisted throughout the year, indicating that sediment transport occurs mainly near the bottom. Durrieu de Madron and Panouse [18] and Durrieu de Madron et al. [19] provided evidence of several processes that export sediments from the shelf: bottom Ekman transport driven by the cyclonic

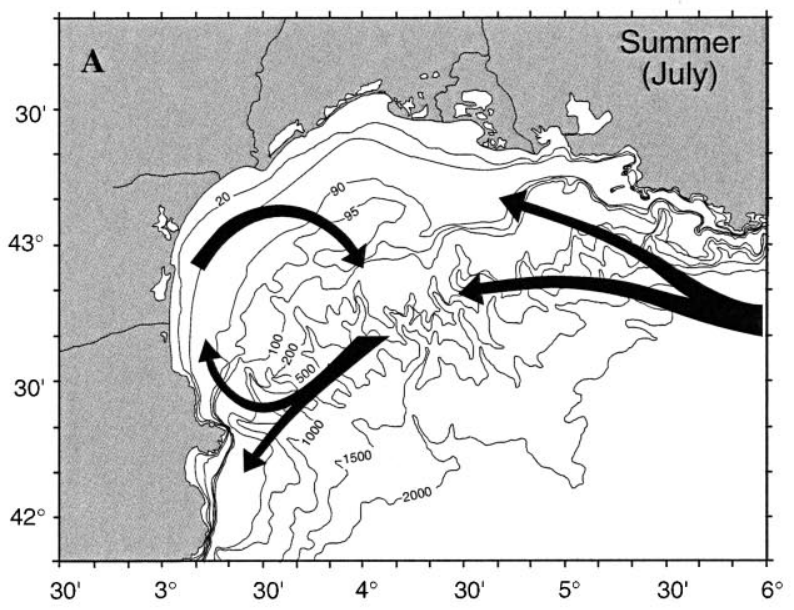

circulation, dense water cascading in winter, and meandering of the along-slope current. Lapouyade and Durrieu de Madron (submitted) calculated the geostrophic transport of PM and associated POC over the whole water column that crosses a section encircling the Gulf of Lions (figure 1). They estimated an overall annual PM export from the Gulf of Lions of about $1.9 \times 10^{6} \mathrm{~T} \cdot \mathrm{y}^{-1}$ and a POC export of about $18 \times 10^{4} \mathrm{~T} \cdot \mathrm{y}^{-1}$. These fluxes are based on two extreme values, i.e., the maximum winter and minimum summer exports. The relative uncertainty on these estimates is assumed to be of about $50 \%$.

\subsection{Inputs of PM and POC to the Gulf of Lions water column}

The inputs of PM to the Gulf of Lions derive from primary production, river discharge and the atmospheric deposition.

\subsubsection{Primary production over the shelf and slope}

The average annual primary production measured in 1993-1994 at a single location on the upper slope off Marseilles was estimated to be about 140-150 $\mathrm{gC} \cdot \mathrm{m}^{-2} \cdot \mathrm{y}^{-1}[14]$. This value is close to the estimate of Cruzado and Velasquez [16] of about 120 $\mathrm{gC} \cdot \mathrm{m}^{-2} \cdot \mathrm{y}^{-1}$, inferred from nutrient measurements over the entire Gulf of Lions. Lefevre et al. [28]

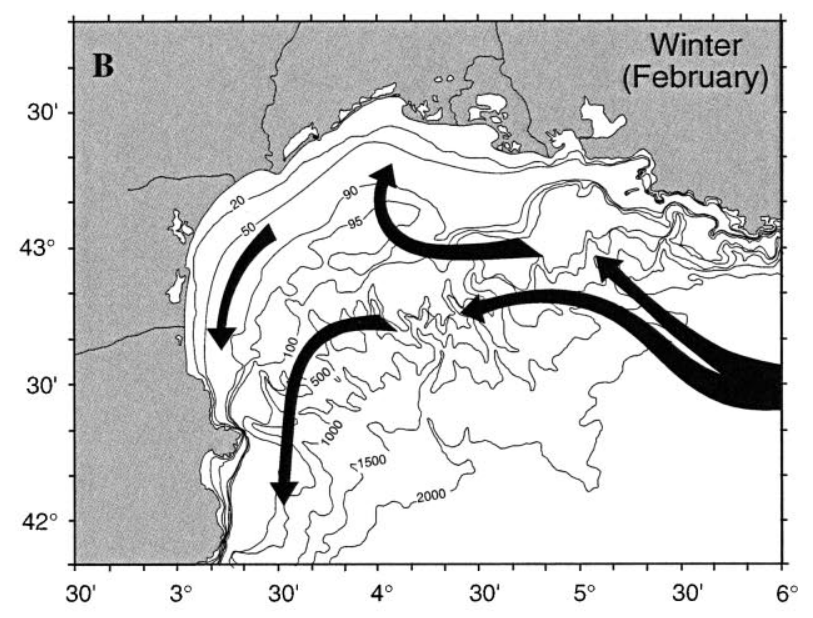

Figure 4. Schematic representation of the summer (July) and winter (February) regional water circulation retraced from the surface velocity fields calculated using a general circulation model after Thunus [42]. 
estimated for this area a mean primary production between 78 and $142 \mathrm{gC} \cdot \mathrm{m}^{-2} \cdot \mathrm{y}^{-1}$ based on in situ and in vitro net community production. We therefore assumed an average primary production of $120 \pm 30$ $\mathrm{gC} \cdot \mathrm{m}^{-2} \cdot \mathrm{y}^{-1}$ on the total surface of the Gulf of Lions $\left(2.16 \times 10^{10} \mathrm{~m}^{2}\right)$, which lead to a total POC production of about $260 \pm 60 \times 10^{4} \mathrm{~T} \cdot \mathrm{y}^{-1}$. The production of algal biomass (PM), which can be estimated according to Strickland [41] to be roughly 3 times the carbon production, amounts to about $7.8 \pm 1.8 \times 10^{6}$ $\mathrm{T} \cdot \mathrm{y}^{-1}$.

\subsubsection{The Rhone and other small rivers}

The Rhone river is the major source of PM providing more than $80 \%$ of the total riverine input to the Gulf of Lions [3]. From a one-year study of the Rhone discharge at Arles $(50 \mathrm{~km}$ upstream of the river mouth), Pont [35] estimated that the mean PM discharge for the 1961-1996 period amounted to $6.2 \times$ $10^{6} \mathrm{~T} \cdot \mathrm{y}^{-1}$. More recently, Sempéré et al. ([39] in press) estimated, from the same data set, the mean ( \pm standard deviation) annual PM and POC discharges over the last decade to be about $9.9 \pm 6.5 \times$ $10^{6} \mathrm{~T} \cdot \mathrm{y}^{-1}$ and $19.4 \pm 11.0 \times 10^{4} \mathrm{~T} \cdot \mathrm{y}^{-1}$, respectively. These authors also estimated that the refractory fraction of POC was about $80 \%$. Using the results of Sempéré et al. (in press), the total riverine supply to the Gulf of Lions was estimated to be about $12.4 \pm$ $5.9 \times 10^{6} \mathrm{~T} \cdot \mathrm{y}^{-1}$ for PM and $24 \pm 10 \times 10^{4} \mathrm{~T} \cdot \mathrm{y}^{-1}$ for POC. Part of the POC discharge can be retained in the estuary by mineralization and sedimentation or contribute to the coastal water primary production after degradation by bacteria. However, such losses of POC have so far not been estimated. Taking into account that the riverine organic matter is mostly refractory, we assumed that the entire river supply reaches the aphotic shelf waters without alteration or deposition. This approximation probably overestimates the river contribution, but seems reasonable for the first order budget calculations that we attempted to draw here.

\subsubsection{Atmospheric inputs}

The overall atmospheric POC deposits on the Gulf of Lions are quite low. They mainly occur close to the coast due to the northern wind (Mistral) that transports particulate carbon in the dry form (pollution aerosols and plant fragments) (Löye-Pilot, pers. comm.). As this input is undocumented, we estimated the total POC deposition (wet + dry) using measurements collected over 11 years in Corsica [29, 30]. These authors estimated the mean $( \pm$ standard deviation) annual atmospheric particulate and POC fallout to be about $12.5 \pm 7 \mathrm{~g} \cdot \mathrm{m}^{-2} \cdot \mathrm{y}^{-1}$ and 0.3 $\mathrm{gC} \cdot \mathrm{m}^{-2} \cdot \mathrm{y}^{-1}$, respectively. For the Gulf of Lions, this leads to a particulate input of about $0.3 \pm 0.2 \times 10^{6}$ $\mathrm{T} \cdot \mathrm{y}^{-1}$ and a POC input of about $0.6 \pm 0.3 \times 10^{4}$ $\mathrm{T} \cdot \mathrm{y}^{-1}$ (the uncertainty on POC input was estimated assuming the same relative uncertainty as for the PM input).

\subsection{Losses of POC by degradation}

The difference between the estimated POC inputs to and outputs from the Gulf of Lions water column (table II) implies that between 3 and $15 \%$ (average $8 \%$ ) of the inputs are buried in the shelf and the slope sediments, and that 3-13\% (average 6\%) escape by advection to the adjacent deep basin. The remaining POC (72-94\%) is likely to be lost through oxidation or metabolization. This loss can take place either in the water column or at the sediment-water interface.

\subsubsection{Degradation in the photic layer}

A large fraction of the primary production is recycled within the photic layer, whereas the remainder escapes to the aphotic water layer. It is generally as-

Table II. Inputs and outputs of particulate matter and particulate organic carbon in the Gulf of Lions.

\begin{tabular}{|c|c|c|}
\hline Terms & $\begin{array}{l}\text { Particulate matter fluxes } \\
\left(10^{6} \mathrm{~T} \cdot \mathrm{y}^{-1}\right)\end{array}$ & $\begin{array}{l}\text { POC fluxes } \\
\left(10^{4} \mathrm{~T} \cdot \mathrm{y}^{-1}\right)\end{array}$ \\
\hline River supply & $12.4 \pm 5.9$ & $24.0 \pm 10.0$ \\
\hline Atmospheric fallout & $0.3 \pm 0.2$ & $0.6 \pm 0.4^{\mathrm{a}}$ \\
\hline Primary production ${ }^{\mathrm{a}}$ & $7.8 \pm 1.8^{\mathrm{a}}$ & $260.0 \pm 60.0^{\mathrm{a}}$ \\
\hline Total inputs & $20.5 \pm 7.9$ & $284.6 \pm 70.4$ \\
\hline Advective export & $1.9 \pm 1.0^{\mathrm{a}}$ & $18.0 \pm 9.0^{\mathrm{a}}$ \\
\hline Sediment burial & $27.4 \pm 13.0$ & $22.5 \pm 10.7$ \\
\hline $\begin{array}{c}\text { Water/sediment } \\
\text { degradation }\end{array}$ & no value & $33.8 \pm 16.1^{\mathrm{a}}$ \\
\hline $\begin{array}{l}\text { Photic layer } \\
\text { degradation }\end{array}$ & no value & $234.0 \pm 54.0^{\mathrm{a}}$ \\
\hline $\begin{array}{r}\text { Aphotic layer } \\
\text { degradation }\end{array}$ & no value & 4.0 \\
\hline Total outputs & & $312.3 \pm 89.8$ \\
\hline
\end{tabular}

${ }^{a}$ Estimated confidence interval. 
sumed that the flux of POC escaping the photic layer is equivalent to the new production. However, the work of Copin-Montégut and Avril [15] in the nearby Ligurian Sea, east of the Gulf of Lions, suggests that a large part of the exportable carbon is in the dissolved form. The export of dissolved organic carbon (DOC) results mostly from convection processes in the wintertime, when the water is weakly stratified, and from turbulent diffusion during the other seasons. From a nitrogen budget in the Gulf of Lions, Conan et al. [14] estimated that about $86 \%$ of the downward nitrogen flux was related to diffusion and advection of dissolved organic nitrogen. In the absence of present estimates of the exportable DOC and POC fluxes, we assessed the exported POC by comparing the mean annual trap-measured POC flux below the surface layer with the average primary production, both measurements being performed in the same oceanic region off Marseilles. The trap fluxes result from a one-year experiment carried out at a nominal depth of $80 \mathrm{~m}$ in the Grand-Rhone Canyon (bottom depth of $900 \mathrm{~m}$ ) described in Monaco et al. [34]. The trap was located immediately below the maximum mixed-layer depth and the photic zone that was about $70 \mathrm{~m}$ thick [14]. Durrieu de Madron et al. [19] and Monaco et al. [34] indicated that particulate fluxes collected by this trap were little affected by direct river and atmospheric inputs, and that the organic matter was constituted of phytoplanktonic material. The difference between the primary produced carbon $\left(120 \mathrm{gC} \cdot \mathrm{m}^{-2} \cdot \mathrm{y}^{-1}\right)$ and the yearly POC flux at $80 \mathrm{~m}$ depth $\left(11.7 \mathrm{gC} \cdot \mathrm{m}^{-2} \cdot \mathrm{y}^{-1}\right)$ suggests that $10 \%$ of the POC is removed from the surface layer. Compared to the f-ratio of $0.3-0.37$ generally found in the Gulf of Lions [14], this suggests that the POC contribution to the total organic carbon export ranges from $30 \%$ to $50 \%$. Consequently, the POC recycled in the photic zone or degraded and exported in dissolved form could amount to $90 \%$ of the primary production. The uncertainty on this latter estimate is expected to be quite large due to the potential spatial heterogeneity of the removal processes, in particular vertical mixing and vertical migration of zooplankton, as well as the errors associated with trap measurements (swimmers, solubilization of carbon within the trap and hydrodynamic effects).

By applying a degradation rate of $90 \%$ for the whole Gulf of Lions, one obtains a POC loss rate in the photic layer of about $234 \pm 54 \times 10^{4} \mathrm{~T} \cdot \mathrm{y}^{-1}$.

\subsubsection{Degradation in the aphotic water layer}

Biological particles produced in the surface slope waters are transported westward during their transit in the water column by the strong along-slope circulation. Consequently, primary-produced particles that settle on the Gulf of Lions continental slope most probably originate from regions upstream of the Gulf of Lions. We assumed that the primary production in these regions is similar to that in the Gulf of Lions.

POC degradation still occurs below the photic zone, so the POC pool decreases as particles settle. Typical oceanic degradation rates can be inferred from the widely used empirical relationships describing particle fluxes summarized by Bishop [6]. We used the relation $\mathrm{J}=\mathrm{J}_{100} /\left((\mathrm{z} / 100)^{0.858}\right)$ put forward by Martin et al. [31], that provides the best estimates of particle flux and degradation. This relation only depends on the depth (z) and the flux at $100 \mathrm{~m}\left(\mathrm{~J}_{100}\right)$. Using the aforementioned trap-measured POC flux $\left(11.7 \mathrm{gC} \cdot \mathrm{m}^{-2} \cdot \mathrm{y}^{-1}\right)$ as the best estimate of the flux at $100 \mathrm{~m}$, the POC loss varied between $5 \times 10^{-2} \mathrm{gC} \cdot \mathrm{m}^{-3} \cdot \mathrm{y}^{-1}$ around $200 \mathrm{~m}$ and $4 \times 10^{-4} \mathrm{gC} \cdot \mathrm{m}^{3} \cdot \mathrm{y}^{-1}$ around $2000 \mathrm{~m}$.

By integrating the loss of POC over the volume of the Gulf of Lions between 100 and $2000 \mathrm{~m}$ depth, the total loss of POC in the aphotic water layer is estimated to be about $4 \times 10^{4} \mathrm{~T} \cdot \mathrm{y}^{-1}$.

\subsubsection{Degradation at the sediment-water interface}

Near-bottom fluxes of PM and POC were measured using sediment traps collecting particles $30-50 \mathrm{~m}$ above the bottom on the upper slope of the Gulf of Lions (figure 1). The original data are presented in Monaco et al. [33, 34] and Heussner et al. [25]. Annual mean mass fluxes measured a few years apart for the same locations and depths, were very similar and were averaged. The confidence interval of annual mean fluxes from a 5 -year time series at the entrance and at the exit of the Gulf of Lions was $\pm 20 \%$ (Heussner, unpubl. results). This value was used to assign an uncertainty to the different flux values given in table III. Particulate fluxes from the different sites were interpolated over the entire continental slope between 200 and $1000 \mathrm{~m}$ depth taking into account the discrepancy between canyons and open-slopes as well as between the eastern and western halves of the continental slope. We further considered that canyons covered half of the slope area. 
The eastern part of the slope - from the Planier Canyon to the Sète Canyon - exhibits low fluxes, about three times lower than those observed on the western part (figure 5). Furthermore, fluxes within the canyons are generally higher than those recorded on the adjacent open slopes. The annual flux of PM on the continental slope between 200 and $1000 \mathrm{~m}$ depth is estimated to be about $4.5 \pm 0.9 \times 10^{6} \mathrm{~T} \cdot \mathrm{y}^{-1}$. POC content of the trapped material is higher on the eastern part of the slope $(2.2 \%)$ than on the western

Table III. Annual fluxes of particulate matter and particulate organic carbon on the eastern and western halves of the continental slope of the Gulf of Lions estimated from near-bottom sediment trap measurements (figure 5).

\begin{tabular}{llllll}
\hline Particle fluxes & $\begin{array}{l}\text { Area } \\
\left(\mathrm{km}^{2}\right)\end{array}$ & $\begin{array}{l}\text { Mean accumulation } \\
\text { rate }\left(\mathrm{g} \cdot \mathrm{m}^{-2} \cdot \mathrm{d}^{-1}\right)\end{array}$ & $\begin{array}{l}\text { Mean POC } \\
\text { content }(\%)\end{array}$ & $\begin{array}{l}\text { Mass deposition } \\
\left(\mathrm{T} \cdot \mathrm{y}^{-1}\right)\end{array}$ & $\begin{array}{l}\text { POC deposition } \\
\left(\mathrm{T} \cdot \mathrm{y}^{-1}\right)\end{array}$ \\
\hline $\begin{array}{l}\text { Eastern slope } \\
\text { Canyon }\end{array}$ & 750 & $2.0 \pm 0.4$ & 2.2 & $0.7 \pm 0.1 \times 10^{6}$ & $1.6 \pm 0.3 \times 10^{4}$ \\
$\begin{array}{c}\text { Open slope } \\
\text { Western slope }\end{array}$ & 750 & $0.6 \pm 0.1$ & 2.2 & & $7.0 \pm 1.4 \times 10^{4}$ \\
$\quad$ Canyon & 1200 & $7.0 \pm 1.4$ & 1.5 & $3.8 \pm 0.8 \times 10^{6}$ & \\
Open slope & 1200 & $1.6 \pm 0.3$ & 2.2 & & \\
\hline
\end{tabular}

${ }^{\mathrm{a}}$ Eastern part of the upper slope $\left(\right.$ area $\left.=2400 \mathrm{~km}^{2}\right)$.

${ }^{\mathrm{b}}$ Western part of the upper slope $\left(\right.$ area $\left.=1500 \mathrm{~km}^{2}\right)$.

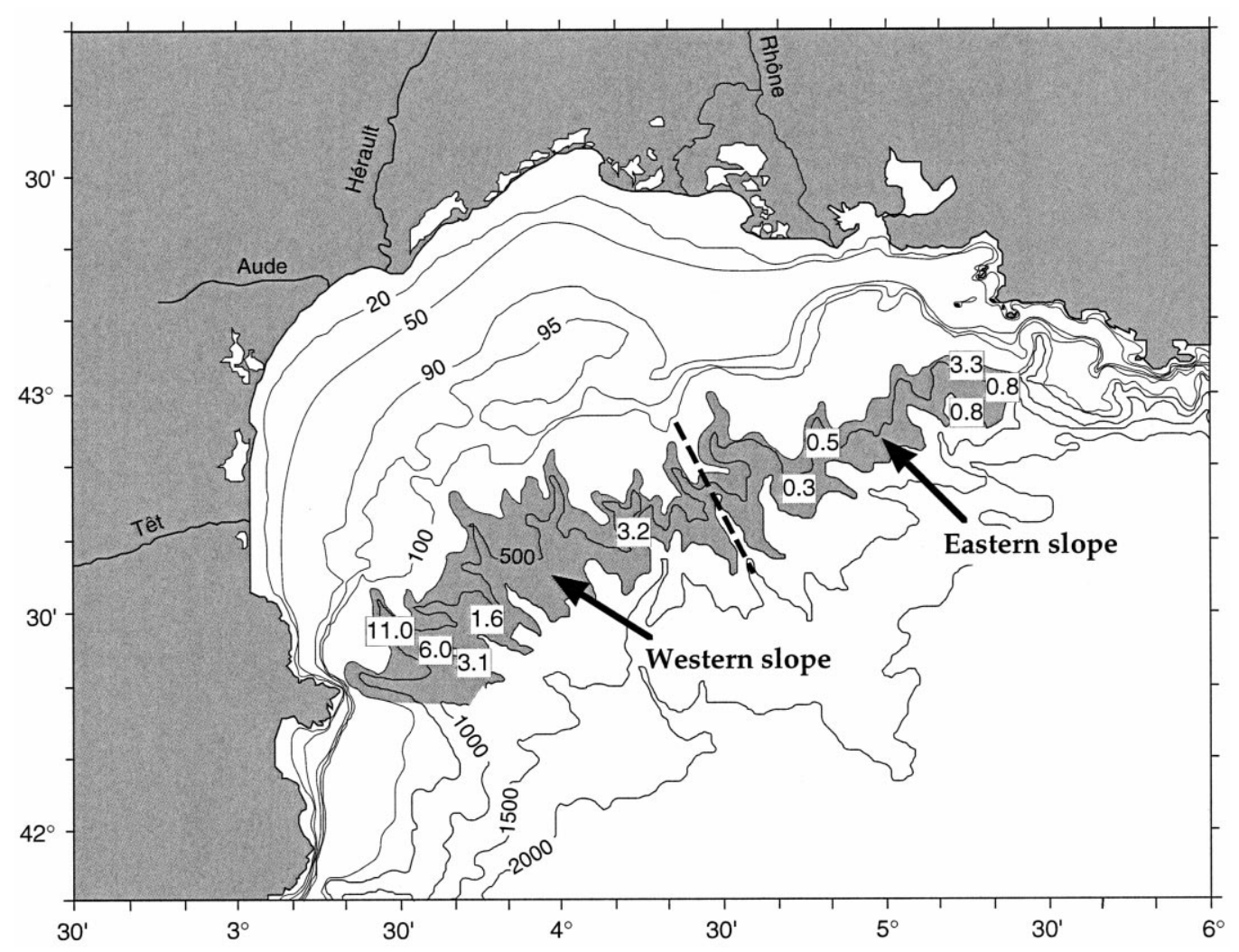

Figure 5. Annual near-bottom particulate mass fluxes (30-50 m above bottom) on the continental slope between 200 and $1000 \mathrm{~m}$ depth. The slope was halved into an eastern part, characterized by low exportation, and a western part with large exportation. Numbers indicate annual mean mass fluxes $\left(\mathrm{g} \mathrm{m}^{-2} \mathrm{y}^{-1}\right)$ collected by sediment traps at each site. Mean fluxes in the canyons are about twice those of the adjacent open slopes. 
part $(1.85 \%)$. This latter value is the average of the low POC concentrations measured in canyons $(1.5 \%)$ and those measured on the open slopes $(2.2 \%)$. Annual near-bottom flux of POC on the continental slope between 200 and $1000 \mathrm{~m}$ depth is estimated to be $8.6 \pm 1.7 \times 10^{4} \mathrm{~T} \cdot \mathrm{y}^{-1}$.

The degradation of POC at the sediment-water interface was estimated from the comparison of the nearbottom sediment traps mass and POC fluxes to the mass and POC sinks on the upper slope (figure 6). If the sediment that accumulates on the upper slope only derives from the settling of particles (fluxes measured by sediment traps), the particle flux in excess is likely to be transported laterally in the bottom layer. We further assumed that the particle flux reaching the seafloor has a POC content similar to that of the trapped material. The difference between the POC flux assumed to reach the surface of the sediment $\left(6.7 \times 10^{4} \mathrm{~T} \cdot \mathrm{y}^{-1}\right)$ and the POC flux sequestered in the underlying sediment $\left(2.7 \times 10^{4}\right.$ $\left.\mathrm{T} \cdot \mathrm{y}^{-1}\right)$ implies that $4.0 \times 10^{4} \mathrm{~T} \cdot \mathrm{y}^{-1}(60 \%)$ of the incoming POC are degraded. Variations of the nearbottom fluxes and sediment burial within their confidence intervals do not affect the degradation rate, but greatly change the near-bottom advection. This latter

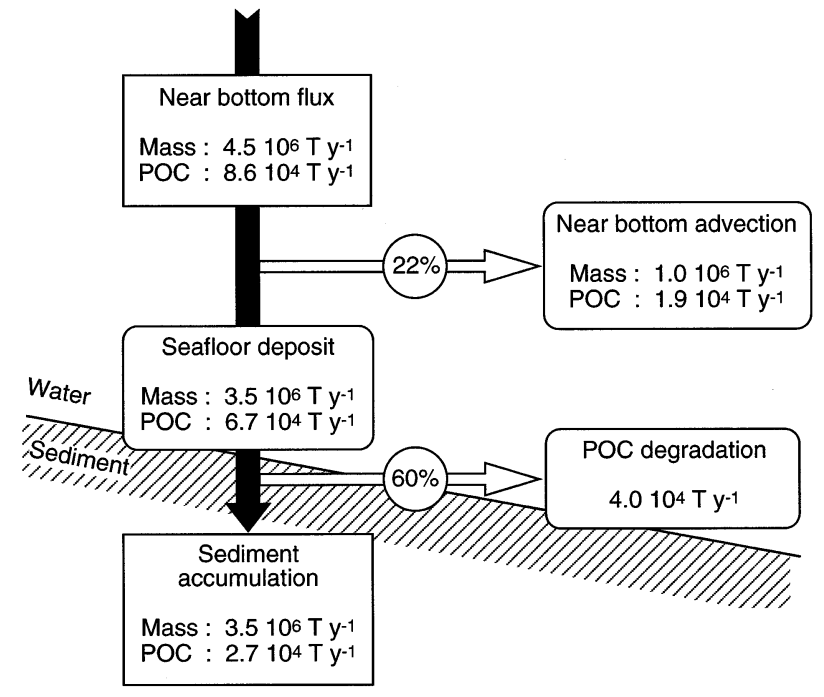

Figure 6. Diagram of the particulate matter and particulate organic carbon budgets at the sediment-water interface on the upper slope $(200-1000 \mathrm{~m})$ of the Gulf of Lions. Input was inferred from near-bottom sediment trap fluxes $(30-50 \mathrm{~m}$ above the bottom). Accumulation in the sediment corresponds to the secular sedimentation. transport is close to zero when the incoming particulate flux is minimized and the sediment burial maximized. It represents $44 \%$ of the incoming flux for the converse situation. It is noteworthy that such a nearbottom transport exports about $1.0 \pm 1.0 \times 10^{6} \mathrm{~T} \cdot \mathrm{y}^{-1}$ of PM and $2.0 \pm 2.0 \times 10^{4} \mathrm{~T} \cdot \mathrm{y}^{-1}$ of POC out of the upper slope region. If this transport were directed to the deeper environment, it could fuel a large fraction of the sedimentation of PM $\left(1.8 \pm 0.6 \times 10^{6} \mathrm{~T} \cdot \mathrm{y}^{-1}\right)$ and POC $\left(1.3 \pm 0.4 \times 10^{4} \mathrm{~T} \cdot \mathrm{y}^{-1}\right)$ on the lower slope.

Using a degraded fraction at the sediment-water interface of $60 \%$, the average degradation rate on the upper slope surface $\left(3.9 \times 10^{9} \mathrm{~m}^{2}\right)$ is about $10.4 \pm 1.4$ $\mathrm{gC} \cdot \mathrm{m}^{-2} \cdot \mathrm{y}^{-1}$. These estimates are close to the degraded fraction of $49 \%$ and degradation rate of 11.5 $\mathrm{gC} \mathrm{m}^{-2} \cdot \mathrm{y}^{-1}$ inferred by Buscail et al. [7] at a single location in the Lacaze-Duthiers canyon. These authors further estimated on the inner shelf next to the Têt river mouth, a degraded fraction of $76 \%$ and a degradation rate of $16.7 \mathrm{gC} \cdot \mathrm{m}^{-2} \cdot \mathrm{y}^{-1}$. These larger values probably result from an enhanced benthic activity due to the proximity of the river and the shallow water depth $(\sim 30 \mathrm{~m})$.

Therefore, we assumed that the average degradation rate of POC at the sediment-water interface on the shelf and slope is $60 \%$. With a POC preservation in the sediment of the Gulf of Lions of $22.5 \pm 10.7 \times 10^{4}$ $\mathrm{T} \cdot \mathrm{y}^{-1}$, we can expect a loss by degradation of $33.8 \pm$ $16.1 \times 10^{4} \mathrm{~T} \cdot \mathrm{y}^{-1}$.

\subsection{POC and PM budget in the Gulf of Lions}

Before examining the possible balance of the POC and PM budget, it is necessary to raise the question concerning the steady state of the system. Although this assumption is probably verified in the long term, it may not remain valid on yearly or decadal time scales, especially if the system undergoes significant natural or anthropogenic modifications. Concerning the inputs, Pont [35] indicated that the PM discharge of the Rhone was likely to be reduced by the intensive dam construction undertaken during the second half of the century. Other parameters can also play a part, like the variations of climatic conditions or the reduction of erosion by the growing forested surface of the catchment areas. 
Another difficulty comes from the mixing of different time scales of the measurements, ranging from the yearly scale, for physical transport processes and particulate fluxes, to a century scale for sedimentation rates deduced from radionuclides. It would obviously be preferable that the time scales of the various components be comparable.

Lastly, one has to keep in mind the biases or errors that can distort the budget. Any biases on the primary production, which has only been studied locally and remains uncertain at the scale of the Gulf itself, directly conditions the losses by degradation in the water column. The main concern comes from the sediment burial, which is overestimated since ${ }^{210} \mathrm{~Pb}$ derived accumulation rates only provide maximum rates. However, there is presently no other way to determine the most recent accumulation at the regional scale more precisely.

Assuming a short-term steady state, the combination of the primary produced POC, terrestrial POC delivered by rivers and the atmosphere, leads to a POC input of about $284.6 \pm 70.4 \times 10^{4} \mathrm{~T} \cdot \mathrm{y}^{-1}$ (table II). About $238 \pm 54 \times 10^{4} \mathrm{~T} \cdot \mathrm{y}^{-1}$ of this quantity are recycled or degraded in the water column, $33.8 \pm 16.1 \times$ $10^{4} \mathrm{~T} \cdot \mathrm{y}^{-1}$ are degraded at the sediment-water interface, $22.5 \pm 10.7 \times 10^{4} \mathrm{~T} \cdot \mathrm{y}^{-1}$ are buried in the sediment and $18 \pm 9 \times 10^{4} \mathrm{~T} \cdot \mathrm{y}^{-1}$ escape the Gulf of Lions. This entails a deficit of about $28 \pm 52 \times 10^{4}$ $\mathrm{T} \cdot \mathrm{y}^{-1}$ in the aphotic water column. Given the magnitude of the input and output uncertainties, in particular those of the primary production and degradation, the POC budget cannot be regarded as significantly different from zero.

Another constraint on the interpretation of the POC budget arises from the analysis of the mass budget. Supply of allochthonous PM from rivers and the atmosphere, together with the autochthonous contribution derived from the primary production, produce a total input of about $20.5 \pm 7.9 \times 10^{6} \mathrm{~T} \cdot \mathrm{y}^{-1}$. The outputs (sediment burial and advective export) amount to $29.3 \pm 14 \times 10^{6} \mathrm{~T} \cdot \mathrm{y}^{-1}$. Without considering internal losses by degradation, the mass budget is in deficit. However the large uncertainties in the data, notably in the river input and sediment burial, do not enable us to reject the possibility of a balanced mass budget.

\section{CONCLUSIONS}

This work presents a synthesis of sedimentological and biogeochemical results gathered in the Gulf of Lions, with the aim of quantifying the transfer of particulate matter (in general) and of POC (in particular) from its introduction to and formation in the shelf and slope waters, to its consumption or sedimentation within the limits of the Gulf or its transfer to the deep sea. Mass and POC budgets were balanced within uncertainties. Nevertheless, these results illustrate the difficulty in establishing budgets based on elements estimated at different time scales, for which the system is not necessarily in a steady state.

A number of conclusions may be drawn from the analysis of these data:

1. Rivers, particularly the Rhône, deliver the major part of the terrestrial material to the Gulf of Lions. Whereas prodeltas are sustained by rivers, the geometry of the major sedimentary units on the shelf highlights the influence of the mean cyclonic circulation on the westward and alongshore dispersion of PM.

2. The characteristics of the sediment on the slope, and especially the intensity of particulate fluxes collected by sediment traps, indicate a PM export from the shelf mainly towards the western half of the slope. Near-bottom advection of PM across the upper slope probably contributes to the bulk of the sedimentation on the lower slope. Quantitatively, the PM deposits on the continental slope are lower by a factor of 2 to 6 than those on the shelf. A small fraction (average $9 \%$ ) of the total PM inputs to the Gulf of Lions water column are exported towards the adjacent North-Balearic basin by the along-slope circulation.

3. For POC, sediment burial on the shelf and slope and advective export to the adjacent deep basin represent a small fraction (respectively $8 \%$ and $6 \%$ on average) of the total POC inputs.

4. The results on degradation suggest that about $90 \%$ of the pool of phytoplanktonic POC produced in the photic layer are recycled or exported in the dissolved form. Furthermore, most of the POC degradation below the surface layer occurs at the sediment-water interface. We estimated that about $60 \%$ of the POC reaching the seafloor was degraded at the sediment-water interface. 


\section{Acknowledgements}

This research was part of the Programme National d'Océanographie Côtière (PNOC), the ECOMARGE-France-JGOFS program, the EUROMARGE-NB and METRO-MED projects. We acknowledge support from the CNRS-INSU, IFREMER and the European Commission's Marine Science and Technology (MAST) Program under contract MAS2-CTP93-0052 and MAS3-CTP960049 .

\section{REFERENCES}

[1] Abassi A., 1998. Contribution à l'étude des transferts particulaires sur la marge continentale du golfe du Lion (Méditerranée Nord-Occidentale), Utilisation de traceurs radioactifs: le Plomb-210 et le Polonium-210, thèse doct. univ. Perpignan, $154 \mathrm{p}$.

[2] Aloisi, J.C., Cauwet, G., Gadel, F., Got, H., Monaco, A., Vile, F., Causse, C., Pagnon, M., 1976. Contribution à l'étude de la sédimentation récente et de la pollution sur le plateau continental du golfe du Lion entre Fos-sur-Mer et Sète. Bull. Bur. Rech. Geol. Min. 4, 69-83.

[3] Aloisi, J.C., Auffret, G.A., Auffret, J.P., Barusseau, J.P., Hommeril, P., Larsonneur, C., Monaco, A., 1977. Essai de modélisation de la sédimentation actuelle sur les plateaux continentaux français. Bull. Soc. Geol. Fr. 7, 183-195.

[4] Anderson, R.F., Bopp, R.F., Buesseler, K.O., Biscaye, P.E., 1988. Mixing of particles and organic constituents in sediments from the continental shelf and slope off Cape Cod: SEEP-I results. Cont. Shelf Res. 8, 925-946.

[5] Bauer, J.E., Druffel, E.R.M., 1998. Ocean margins as a significant source of organic matter to the deep open ocean. Nature $392,482-485$.

[6] Bishop, J.H.B., 1989. Regional extremes in particulate matter composition and fluxes: Effects on the chemistry of the ocean interior. In: Berger, W.H., Smetacek, V.S., Wefer, G. (Eds.), Productivity of the ocean: Present and Past. John Wiley and Sons Ltd, pp. 117-137.

[7] Buscail, R., Pocklington, R., Daumas, R., Guidi, L., 1990. Fluxes and budget of organic matter in the benthic boundary layer over the northwestern Mediterranean margin. Cont. Shelf Res. 10, 1089-1122.

[8] Buscail, R., Pocklington, R., Germain, C., 1995. Seasonal variability of the organic matter in a sedimentary coastal environment: sources, degradation and accumulation (continental shelf on the Gulf of Lions-northwestern Mediterranean). Cont. Shelf Res. 15, 843-869.

[9] Buscail, R., Ambatsian, P., Monaco, A., Bernat, M., 1997. $210 \mathrm{~Pb}$, manganese and carbon: indicators of focusing processes on the northwestern Mediterranean continental margin. Mar. Geol. 137, 271-286.

[10] Buscail, R., Germain, C., 1997. Present-day organic matter sedimentation on the NW Mediterranean margin: Importance of off-shelf export. Limnol. Oceanogr. 42, 217-229.
[11] Calmet, D., Fernandez, J.M., 1990. Caesium distribution in northwest Mediterranean seawater, suspended particles and sediments. Cont. Shelf Res. 10, 895-914.

[12] Cauwet, G., 1981. Non-living particulate organic matter. In: Duursma, E.K., Dawson, R. (Eds.), Marine Organic Chemistry. Elsevier, Amsterdam, pp. 71-89.

[13] Charmasson, S., Radakovitch, O., Arnaud, M., Bouisset, P., Pruchon, A.S., 1998. Long-core profiles of 137Cs, 134Cs, $60 \mathrm{Co}$ and $210 \mathrm{~Pb}$ in sediment near the Rhone river mouth (Northwestern Mediterranean). Estuaries 21, 367-378.

[14] Conan, P., Pujo-Pay, M., Raimbault, P., Leveau, M., 1998. Variabilité hydrologique et biologique au sein du Courant Nord Méditerranéen à l'entrée du golfe du Lion, II. Bilan de la productivité sur le bord interne du courant. Oceanol. Acta 21, 767-781.

[15] Copin-Montégut, G., Avril, B., 1993. Vertical distribution and temporal variation of dissolved organic carbon in the NorthWestern Mediterranean Sea. Deep-Sea Res. 40, 1963-1972.

[16] Cruzado, A., Velasquez, Z.R., 1990. Nutrients and phytoplankton in the Gulf of Lions, northwestern Mediterranean. Cont. Shelf Res. 10, 931-942.

[17] DeMaster, D.J., McKee, B.A., Nittrouer, C.A., Jiangchu, Q., Guodong, C., 1985. Rates of sediment accumulation and particle reworking based on radiochemical measurements from continental shelf deposits in the East China Sea. Cont. Shelf Res. 4, 143-158.

[18] Durrieu de Madron, X., Panouse, M., 1996. Transport de matière particulaire en suspension sur le plateau continental du golfe du Lion, Situation estivale et hivernale. C.R. Acad. Sci. Paris 322, 1061-1070.

[19] Durrieu de Madron, X., Radakovitch, O., Heussner, S., LöyePilot, M.D., Monaco, A., 1999. Role of the climatological and current variability on shelf-slope exchanges of particulate matter: Evidence from the Rhone continental margin (NW Mediterranean). Deep-Sea Res. I 46, 1513-1538.

[20] Gadel, F., Charriere, B., Serve, L., Tomellas, L., 1992. Caractérisation chimique des substances humiques et de leurs classes de poids moléculaires dans les dépôts superficiels du delta du Rhône: relations avec leur origine et les conditions du milieu. Oceanol. Acta 15, 61-74.

[21] Gensous, B., Williamson, D., Tesson, M., 1993. Late Quaternary transgressive and highstand deposit of a shelf (Rhone delta, France). Spec. Pub. Int. Ass. Sedim. 18, 197-211.

[22] Got, H., Aloisi, J.C., 1990. The Holocene sedimentation on the Gulf of Lions margin: a quantitative approach. Cont. Shelf Res. 10, 841-856.

[23] Hall J., Smith S., 1996. First report of the JGOFS/LOICZ continental margins task team, LOICZ reports and studies no. 7, JGOFS Report no. 21.

[24] Heussner, S., Ratti, C., Carbonne, J., 1990. The PPS 3 timeseries sediment traps and the trap sample processing techniques used during the ECOMARGE experiment. Cont. Shelf Res. 10, 943-958.

[25] Heussner S., Calafat A., Palanques A., 1996, Quantitative and qualitative features of particle fluxes in the North-Balearic 
basin, in: Canals M., Casamor J.L., Cachi I., Calafat A.M., Monaco A. (Eds.), EUROMARGE-NB final report, MAST II programme, EU, Vol. IIIB, 43-66.

[26] Jago, C.F., Barusseau, J.P., 1981. Sediment entrainment on a wave-graded shelf, Roussillon. France, Mar. Geol. 42, 279-299.

[27] Lapouyade A., Durrieu de Madron X., Seasonal variability of the advective transport of suspended particulate matter and associated organic carbon in the Gulf of Lions (NW Mediterranean), J. Mar. Syst. (submitted).

[28] Lefevre, D., Minas, H.J., Minas, M., Robinson, C., Williams, P.J., Le, B., Woodward, E.M.S., 1997. Review of gross community production, primary production, net community production and dark community respiration in the Gulf of Lions. Deep Sea Res. II 44, 801-832.

[29] Löye-Pilot, M.D., Cauwet, G., Spitzy, A., Martin, J.M., 1992. Preliminary results on atmospheric wet deposition of organic carbon and nitrogen in Corsica. In: Martin, J.M., Barth, H. (Eds.), EROS 2000 Third workshop on the North Western Mediterranean, Water Pollution Research Report, 28. CEC, Brussels, pp. 519-532.

[30] Löye-Pilot, M.D., Martin, J.M., 1996. Saharan dust input to the western Mediterranean: an eleven years record in Corsica. In: Guerzoni, S., Chester, R. (Eds.), The impact of African dust across the Mediterranean. Kluwer, pp. 191-199.

[31] Martin, J.H., Knauer, G.A., Karl, D.M., Broenkow, W.W., 1987. VERTEX: carbon cycling in the northeast Pacific. Deep-Sea Res. 34, 267-286.

[32] Monaco, A., Biscaye, P., Soyer, J., Pocklington, R., Heussner, S., 1990. Particle fluxes and ecosystem response on a continental margin: the 1985-1988 Mediterranean ECOMARGE experiment. Cont. Shelf Res. 10, 809-840.

[33] Monaco, A., Courp, T., Heussner, S., Carbonne, J., Fowler, S.W., Deniaux, B., 1990. Seasonality and composition of particulate fluxes during ECOMARGE-I, western Gulf of Lions. Cont. Shelf Res. 10, 959-988.
[34] Monaco, A., Durrieu de Madron, X., Radakovitch, O., Heussner, S., Carbonne, J., 1999. Seasonal variability of downward biogeochemical fluxes on the Rhone continental margin (NW Mediterranean). Deep-Sea Res. I 46, 1483-1512.

[35] Pont, D., 1997. Les débits solides du Rhône à proximité de son embouchure: données récentes. Rev. Géogr. Lyon 72, $23-33$.

[36] Radakovitch O., 1995. Etude du transfert et du dépôt du matériel particulaire par le polonium 210 et le plomb 210, Application aux marges continentales du Golfe de Gascogne (NE Atlantique) et du Golfe du Lion (NW Méditerranée), thèse doctorat, univ. Perpignan, $185 \mathrm{p}$.

[37] Radakovitch, O., Charmasson, S., Arnaud, M., Bouisset, P., 1999. $210 \mathrm{~Pb}$ and caesium accumulation in the Rhone delta sediments. Estuar. Coast. Shelf Sci. 48, 77-92.

[38] Radakovitch, O., Heussner, S., 1999. Fluxes and budget of $210 \mathrm{~Pb}$ on the continental margin of the Bay of Biscay (northeastern Atlantic). Deep Sea Res. II 46, 2175-2204.

[39] Sempéré R., Charrière B., Cauwet G., Carbon inputs of the Rhone river to the Mediterranean Sea, Global Biogeochem. Cycle (in press).

[40] SOGREAH Delta du Rhône, 1988. Facteurs hydrodynamiques et comportements des sédiments, Rapport 5.219, 33 p.

[41] Strickland, J.D.H., 1960. Measuring the production of marine phytoplankton. Fish. Res. Board Canada Bull. 122, 1-172.

[42] Thunus V., 1996. Modélisation à méso-échelle de l'hydrodynamique et du transport de particules en milieu marin semiouvert, Application au Golfe du Lion, thèse doctorat, univ. Neuchâtel, 152 p.

[43] Zuo, Z., Eisma, D., Berger, G.W., 1991. Determination of sediment accumulation and mixing rates in the Gulf of Lions, Mediterranean Sea. Oceanol. Acta 14, 253-262.

[44] Zuo, Z., Eisma, D., Gieles, R., Beks, J., 1997. Accumulation rates and sediment deposition in the northwestern Mediterranean. Deep-Sea Res. II 44, 597-609. 